Typesetter query for GOV2100047 Au correction

Smith (2009) is cited in text but not provided in the list (see line number 141). Please provide complete publication details to insert in the list, else delete the citation from the text. 


\title{
Core Executive Politics in the Cameron Era, 2010-16: The Dynamics of Whitehall Reform
}

Patrick Diamond (D)

Faculty of Humanities and Social Sciences, School of Politics and International Relations, Queen Mary University of London, London, UK

Corresponding author. Email: p.diamond@qmul.ac.uk

(Received 8 September 2020; revised 10 June 2021; accepted 20 August 2021)

\begin{abstract}
By the early 1990s, the core executive was established as the 'new orthodoxy' in the study of British government at the centre. Thirty years on, this article avers that its main assumptions are increasingly questionable in the light of more recent empirical evidence. The core executive approach may well have outlived its usefulness. This claim is derived from analysis of the Cameron premiership from 2010 to 2016. The focus is on how Whitehall reform radically altered the relationship between politicians and civil servants, reshaping prevailing public service bargains and rules of the game. Ministers identified mechanisms to rebuild political capacity, augmenting partisan control of the bureaucracy. They drew on resources from outside the core executive while politicians increased their sway over civil service appointments. As a result, officials felt they should be 'responsive' to ministers. The cumulative effect was to replace interpersonal and institutional resource dependency with a 'them and us' model. Consequently, the risk of policy disasters and fiascos grew.
\end{abstract}

Keywords: governance; core executive; bureaucratic politics; public policy; meta-governance; UK politics

This article considers the reforms of Whitehall enacted during the administrations of David Cameron from 2010 to 2016. The focus is how the relationship between ministers and officials was radically altered, reshaping prevailing public service bargains and rules of the game. The 2010-16 period stood out since Conservative ministers were determined to overhaul the government machinery. The drivers of institutional reform were austerity and financial constraint, alongside long-standing dissatisfaction with civil service performance. Ministers believed the bureaucracy was inward-looking and risk averse. Cameron's aim was to 'professionalize' government by directly undermining the civil service monopoly over policy advice.

The cumulative effect is to replace interpersonal and institutional resource dependency with a 'them and us' model. As such, the changes called into question the core executive concept as a theoretical approach to understanding modern bureaucratic politics. The term alludes to a cohesive, unified centre of government where goals are pursued through the exchange of resources between interdependent 
actors. Drawing on interviews with Whitehall insiders, both ministers and officials, this article challenges the veracity of the core executive literature.

\section{Administrative reform in the UK: Theoretical framework}

The core executive concept established a 'new orthodoxy' in the study of British government, becoming 'dominant' across the discipline (Elgie 2011: 74; Marinetto 2003). Subsequent accounts incorporate assumptions drawn from that literature given the core executive was analytically sophisticated in comparison to the 'prime ministerial versus cabinet government' framework. The term 'core executive' reflected empirical changes in government after 1979 (Dorey 2020; Smith 1999). Patrick Dunleavy and Rod Rhodes (1990) defined the core executive as 'those organizations and structures which primarily serve to pull together and integrate central government policies, or act as final arbiters within the executive of conflicts between different elements of the government machine'. ${ }^{1}$ This executive comprised actors (the prime minister, cabinet ministers, junior ministers, officials alongside special advisers) and institutions (Number 10, the Cabinet Office, the Treasury and departments). Martin Smith (1999) stipulated the 'core executive' fulfilled three functions: devising government policy; coordinating the Whitehall machine; and driving policy implementation.

There were two theoretical premises that underpinned the core executive approach (Dorey 2020; Smith 1999). The first related to the contingency of power. The literature attests that power is not a zero-sum game. Governing is a process where actors are constantly bargaining over resources. Power is not located in any single actor or institution but is everywhere. Power is 'contingent and relational', dispersed throughout government, and shifts according to context (Elgie 2011: 125); Smith admitted the core executive literature implicitly embraced a 'postmodern' view of power.

The second assumption concerns resource dependency: actors rely on one another to achieve their goals. As Smith (1999: 1) emphasizes, 'The political process is about exchanging resources.' Rather than asserting hierarchical authority, co-dependent actors negotiate with one another. Policymaking in Whitehall is an inherently collaborative process between ministers and officials rather than a chain of command. Smith (1999) cites the example of the prime minister (PM). The PM is formally powerful but dependent on the support of cabinet. Number 10 has relatively few resources. The policy process is driven by departments. It is officials that have 'time, administrative capability, expertise, and knowledge' with capacity to craft legislation, steer the policy agenda, and provide logistical support, resources on which ministers traditionally rely (Smith 1999: 106). The core executive emphasizes that the PM depends on other agents and institutions. As a consequence, the 'prime ministerial versus cabinet government' debate is held to be anachronistic.

As such, the bond between politicians and bureaucrats is fundamental: 'In Britain's executive-dominated system, many major policy decisions are determined by their interaction' (Wilson and Barker 2003: 349). The literature stresses that resource dependency characterizes ministerial-civil service relations. Ministers need civil servants who provide advice and expertise to implement policies. 
Officials need ministers who ensure political legitimacy, bestowing decisions with authority. The core executive foresees a reciprocal contract at the heart of bureaucratic politics. The public service bargain (PSB), a concept originated by Bernard Schaffer (1973), alludes to the 'governing marriage' between ministers and officials. The bargain is an 'implicit or explicit agreement between public servants ... and those they serve' (Hood and Lodge 2006: 6). Christopher Hood and Martin Lodge (2006: 2) observe that the 'underlying bargain' between politicians and civil servants has been altered over the last two decades. In many countries, the demands on civil servants to be responsive to ministers have been growing. Consequently, a 'hybrid' PSB emerged in the UK, blending the traditional loyalty bargain with a New Zealand-style system of contract which enshrines the responsibility on officials to deliver ministerial goals (Van Dorpe and Horton 2011: 3).

The core executive addresses the interaction between ministers and civil servants, reflecting the resources available to each. The bond between bureaucrats and ministers is the essence of the Whitehall model (Campbell and Wilson 1995). Smith (1999: 1) does not deny that power asymmetries exist while he accepts that the degree of resource dependency varies across government. He acknowledges, 'Not all actors have equal resources, and the degree of dependency and the way resources are exchanged are products of the particular context actors face.' Nevertheless, to realize their aims, Smith contends actors work collaboratively.

It is apparent, however, that dissatisfaction with the Whitehall model has grown markedly since the 1990s. Consequently, civil servants have felt disparaged and marginalized. Graham Wilson and Anthony Barker (2003: 368) note that 'atmosphere can count for a lot'. After 2010, power dependency eroded as more external actors and appointees entered government. Ministers were searching for new sources of advice. Lacking means to control officials directly, politicians focused on reshaping the bureaucracy (Wilson and Barker 2003). Power is fluid and contingent, according to post-structuralist theory which influenced the core executive approach. Yet, as Steven Lukes (1974) attests, in developing a 'multidimensional' view of power, particular actors still prevail in the decision-making process due to their privileged access to resources. Politicians, for example, retain the ability to control the agenda, removing issues from debate and reshaping dominant beliefs. Indeed, ministers can subordinate officials. An alternative perspective on power, drawing on Lukes, questions the emphasis in the core executive on resource exchange.

The core executive literature assumed that ministers rule in an era of governance where the state is increasingly hollowed out (Rhodes 2017). A related theme emerged of 'meta-governance'. Meta-governance addresses how the state rebuilds capacity despite fragmentation. Governments must cooperate with diverse, decentred networks to achieve their goals (Sorenson and Torfing 2017). According to Eva Sorenson and Jacob Torfing (2017: 829), ministers seek 'to influence the network, while recognising that it needs a certain degree of autonomy to define its purpose and objectives'. At the same time, 'state-centric' accounts of meta-governance underline that governments use resources to control non-state actors operating 'in the shadow of hierarchy' (Fawcett 2014).

Paul Fawcett (2014) insists hierarchies have not been supplanted. The state retains the capacity to govern (Smith 2009). Meta-governance alludes to 'the 
tools, strategies and relationships used by governments to help govern ... from regulation and legislation to behavioural change' (Bell and Hindmoor 2009: 2). As such, while policies depend on non-state actors, governments use mechanisms, notably targets and performance management, to retain control of policy outcomes.

The meta-governance approach confronts the central state's ability to direct the institutions and actors that comprise the UK's system of governance (Dommett and Flinders 2016). Yet meta-governance adheres to the core executive model's main premise: resource dependency. Networks are self-governing, but ministers and officials cooperate to ensure order, avoiding policy fiascos. Katharine Dommett and Matthew Flinders (2016) demonstrate that the Cabinet Office expanded its control of 'arm's length' public bodies after 2010, responding to the 'coordination dilemma' confronting the core executive in the era of meta-governance. As such, changes in power dependency between ministers and officials are intertwined with changes at the institutional level between the centre of government and Whitehall departments.

Taking into account existing theories, the research question addressed in this article is whether the core executive remains a viable framework for understanding UK government at the centre. The article is structured in the following way. The next section outlines the research design. The article then delineates the reforms enacted during the Cameron premiership, and their implications for the resources at the disposal of ministers and officials. In the final section, the article highlights the consequences of reform, questioning the continuing relevance of the core executive approach.

\section{Research strategy}

The findings are generated using semi-structured interviews. A deductive methodology was employed. The aim was to use interviews to test the continuing relevance of the core executive concept. The research is derived from a decade of scholarly investigation, drawing on 17 semi-structured interviews. A tranche of seven interviews was carried out between 2011 and 2013. Subsequently, ten interviews took place from September 2016 to January 2018 following Cameron's departure. The interviewees comprised two former cabinet secretaries, two permanent secretaries, two special advisers, nine departmental civil servants, alongside two think-tank experts (no actors were reinterviewed).

The interviews make no claims to representativeness. The interviewees merely offer interpretations of bureaucratic politics. Civil servants feature prominently and were invariably critical of the 2010-16 administrations. Moreover, the article is written by a former practitioner (Diamond 2018). It is important to acknowledge the reflexive context of the interviews. Participants might be led to exaggerate their role. They may tell the interviewer what they think she or he wants to hear. Nonetheless, elite interviews with a former official provide a rich data set. The researcher can identify key processes, unpicking how organizations work while scrutinizing actors' interpretations (Boswell et al. 2019).

Moreover, there is scope for 'ongoing dialogue ("reflexivity") between subject and object' (de Volo and Schatz 2004: 268). Interviews remain 'the best available method' to understand how governing elites think, 'opening the black box of life 
at the apex of modern government' (Boswell et al. 2019: 59). Rhodes (2011) produced a landmark study using interviews and participant observation. Lorraine de Volo and Edward Schatz (2004: 269) believe such methods allow researchers to fashion agency-centred explanations, addressing how officials and ministers understand the world. Yet it is important to recognize actors also operate on 'structural terrain' that shapes decisions and behaviour. Realist epistemology acknowledges 'the underlying structures that create the institutional arena within which people act' (Smith 1999: 244). The interviews illuminate the presence of structures in the everyday life of governments.

\section{Analysis: Whitehall reform 2010-16}

The resources available to ministers and civil servants altered during the Cameron premiership. Consequently, power dependency diminished, undermining the main premise of the core executive framework. This section addresses the reforms enacted by Conservative-led administrations between 2010 and 2016. The period offers a compelling case study. The UK was at the forefront of state reform in advanced economies. It is an important example of a 'Westminster model' democracy. Until 2015, Cameron governed in coalition with the Liberal Democrats, led by Nick Clegg. It is argued that Clegg's party had a 'restraining effect' since 'power is more dispersed and government policies arise from negotiations' (Gay et al. 2015: 93). Robert Hazell (2012: 68) concludes that coalition meant the revival of cabinet government.

Yet the Conservatives remained the predominant power. The Liberals were spread thinly across five departments, managing multiple policy agendas from tuition fees to electoral reform (Goes 2016). They had less capacity to oppose Cameron's reforms. Having a free hand enabled the PM to project his modernizing credentials (Dorey 2020). The initial reforms were enacted before the Conservatives secured a parliamentary majority in 2015. Cameron's allies believed the Whitehall machinery must be overhauled. Their agenda drew on 1980s-style 'new public management' (NPM) reforms (Dorey 2014). The analysis was rooted in the new right's critique of public bureaucracy.

Among the most influential of the key actors was the Cabinet Office minister, Francis Maude (Diamond 2018). Maude was a long-standing critic of Whitehall. He believed the traditional bureaucracy was not delivering what ministers wanted. Politicians ascribed less value to resources provided by the civil service: expert knowledge, institutional memory, understanding of bureaucratic/professional linkages. As such, resource dependency was wearing thin. Maude insisted the civil service epitomized the inadequacies of statism. He battled to impose 'private sector nostrums' (interview with former departmental permanent secretary, 6 April 2018). Maude averred, 'The era of big government has come to an end not just because the money has run out ... but it is literally shown to have failed' (cited in Foster 2015). The PM's adviser, Steve Hilton, similarly believed the Whitehall machinery must be cut radically. Policy should be contracted out to think-tanks: 'One of his justifications is that we once ran an empire with only 4,000 civil servants - so how can we justify a Civil Service of 434,000 today just to run Britain?' (cited in Cameron 2017). 
Maude's programme curtailed civil service/ministerial power dependency. Whitehall contracted in size after 2010. Officials had fewer resources. Meanwhile, the reforms strengthened political hierarchy, increasing civil service responsiveness to ministers. The approach meant 'new forms of hierarchical rule' (Pedersen et al. 2011: 379). Maude's plans reshaped central government through two 'interwoven tenets'. Ministers who determine policy should direct public servants who implement policy, reflecting the politics-administration dichotomy. And where necessary, unresponsive bureaucracies must be replaced by the private sector (Bakvis and Jarvis 2012: 12).

Maude's reforms attacked bureaucrats' structural power. The relationship envisaged between ministers and officials was shaped by 'principal-agent' theory. 'Principals' were politicians who set direction. 'Agents' were civil servants who put instructions into effect (Le Grand 2006: 56). The principal-agent distinction stipulates that bureaucracies have interests that thwart politicians (Bakvis and Jarvis 2012; Niskanen 1971). The 2012 Whitehall Reform Plan acknowledged that while NPM overturned traditional hierarchies, it enlarged 'the relative powers of bureaucracies and non-political actors'. Managers acquired 'freedom to manage'; agencies were created outside the operational control of politicians (Peters and Savoie 2012: 30). While ministers could shield themselves from delivery failure, they struggled to avoid blame altogether. ${ }^{2}$

The 2010-16 reforms had three main elements, altering the resources at the disposal of ministers and officials. The first focused on transforming the civil service culture, ensuring officials were responsive and compliant. The second element meant drawing on resources outside the core executive. The post-2010 administrations were determined to end the civil service monopoly, advancing 'open' policymaking. The third element involved strengthening the centre of government. The institutionalization of policy advice in Number 10 continued during Cameron's premiership. The next section examines each of the reforms, highlighting implications for the distribution of resources and the exchange relationship between officials and ministers.

\section{Transforming the culture: $a$ responsive civil service}

The aim was to ensure civil servants were there to serve ministers, undermining power/resource dependency. The number of officials fell dramatically. Between 2010 and 2016, those employed fell from 470,000 to 380,000, the lowest since World War II (Guerin 2020). From 2010 to early 2012, 54,000 posts were cut (Haddon 2016). Departments experienced headcount reductions of 35\%, notably Communities and Local Government (DCLG), Work and Pensions (DWP) alongside Culture, Media and Sport (DCMS). By 2015, there were fewer than 6,000 senior policy officials (Guerin 2020). The loss of institutional capacity and growing insecurity of tenure influenced civil servants' behaviour.

Personalization of civil service appointments

Appointments were increasingly 'personalized'. Personalization did not, of course, begin during the Cameron administrations. Even so, ministers increasingly expected to handpick key officials. Secretaries of state could remove their 
permanent secretary. The power dependency underlined by the 'governing marriage' between politicians and civil servants was threatened. Officials depended on ministerial approval, but politicians were less reliant on them. Ministers created an 'entourage' of loyal staff separate from the bureaucracy.

Ministers sought to control appointments, overcoming bureaucratic resistance. The general attitude, as one adviser remarked, was, 'Civil servants are just obstructive. There is a growing realization that if you don't do stuff in the first two years of a term it just doesn't get done. There's no time for a Whitehall-style box-ticking risk assessment on everything.' After 2010, the turnover of permanent secretaries increased markedly. Data from the Institute for Government (IfG) (Freeguard et al. 2015) indicate that in the first two years of Cameron's premiership, each department on average appointed two different permanent secretaries. The Ministry of Defence (MoD), Department for Transport (DfT) and Cabinet Office (CO) had four permanent secretaries each during that period. Nicholas Macpherson was the only permanent secretary in 2010 still in post in 2015. In contrast, from 1997 to 2010 each department had, on average, just two permanent secretaries (Freeguard et al. 2015). An expert recalled, 'Permanent secretaries got moved on; there was quite a turnover in the 2010-15 period' (interview with Whitehall think-tank director, 30 September 2016).

Ministers favoured 'can-do' officials, echoing the Thatcher era. A former permanent secretary feared it was 'the thin end of the wedge towards politicization' (interview with former departmental permanent secretary, 6 April 2018). The PM wanted ministers to have the final say on appointments. They had been held back:

Rather excessively in recent years so that there is one name and the PM either has to say 'yes' or 'no' ... I don't think we should have ended up in that position. It would have been better for one or two people to get over the line. Then the PM, in conversation with the cabinet secretary and perhaps the secretary of state, to make the decision. I do not think that that's politicisation. I think that's just the ability of a government to make sure it's got the right people in place. (Hansard 2014)

It was proposed that ministers would select permanent secretaries from a shortlist. That was resisted by the Civil Service Commission. They were concerned politicians would exercise influence through 'opaque and undocumented channels':

Selection panels are known to take active steps to avoid the possibility of a veto - to the point of avoiding recommending a candidate likely to be opposed by the Minister. Selection competitions are also run in circumstances where it is more or less known in advance who the successful candidate will be. Managed moves offer another mechanism for undocumented ministerial influence. (Cited in Freeguard et al. 2015)

Maude averred senior officials should be hired directly by ministers, as occurred in New Zealand. After all, ministers were accountable to Parliament. They should have confidence in the permanent secretary. Consequently, Whitehall became more 
porous, addressing skills gaps in finance, human resources, technology and procurement. An observer remarked, 'The civil service has brought in people to run things, HMRC and social security, mainly because these are much more complicated organizations. What the state is trying to do is not as straightforward as in the past' (interview with senior official in the Department for Education and the Ministry of Justice, 7 October 2016).

Michael Gove at the Department of Education pointedly recruited an external appointee as his director of strategy, performance and analysis (Haddon 2016). Yet drawing on outside talent was hardly transformational. Most posts remained unexposed to external competition. Permanent secretaries rose up the traditional career ladder. Even so, the 'job for life' model was under strain: 'The civil service is clearly different to 30 years ago. It is more diverse with a wider range of skills. It is opening up beyond the civil service' (interview with Whitehall think-tank director, 30 September 2016). Power dependency abated as ministers relied less on civil servants. The 'churn' of appointments meant ministers were invariably more experienced than their officials (Rutter 2013). In the UK, that long-term shift converted civil servants from policy advisers into managers (Dunleavy and Rhodes 1990). Rodney Lowe (2011: 1) concludes that the reforms were 'the culmination of the long-frustrated administrative revolution promised by the 1968 Fulton Report: the transmutation of senior officials from "generalist" policy advisers into "professional" managers'.

\section{Departmental boards and appointment of the civil service CEO}

The strengthening of departmental boards in Whitehall through appointment of non-executive directors was significant. Boards were chaired by the secretary of state. They could 'scrutinize delivery' and departmental business plans, merging politics and management. External appointees intervened in personnel and finance decisions (McClory 2010). Elsewhere, John Manzoni was appointed civil service CEO in October 2014 to strengthen procurement, establishing the Major Projects Authority (MPA) managing 188 high-risk projects worth $£ 489$ billion (Haddon 2016).

In this context, it was believed civil servants were less inclined to 'speak truth to power' (Wildavsky 1979). Officials became more cautious and apprehensive (Aucoin 2012; Sausman and Locke 2004: 112). The National Audit Office (NAO) criticized permanent secretaries for being 'too responsive to the political demands of Ministers, and insufficiently attentive to their duties as accounting officers' (cited in Pearce 2016). An observer admitted, 'The senior civil service's ability to offer frank advice has been cowed' (cited in Freeguard et al. 2015). Almost 30 years ago, David Butler et al. (1994: 214) highlighted the 'activist mentality' where officials are determined to pursue ministerial policies enthusiastically, demonstrating loyalty. The study was confined to the Thatcher government's plans for local government taxation, replacing rates with a 'poll tax'. Decades later, the activist mentality is becoming ubiquitous in Whitehall.

\section{Extended ministerial offices}

In increasing the resources available to ministers, the Cameron administration established extended ministerial offices (EMOs). EMOs enabled ministers to recruit 
chosen appointees. The PM justified EMOs in providing 'some experts, a bit of implementation, some special advisers. That's quite like what the PM has. It's quite like what some Ministers have already put in place. I think it's growing organically. I'm helping giving it a nudge along' (Hansard 2014). As a result, the conveyor belt from think-tanks into government gathered speed, raising concerns about the 'patronage state'. Giving evidence to the Public Administration Select Committee (PASC), Lord Hennessy warned of 'seeping politicisation' (House of Commons 2013a). EMOs 'risk[ed] becoming institutionalised cocoons impervious to dissenting opinions or unwelcome facts' (cited in Richardson 2018: 220). Ministers would be shielded from unwelcome advice. In Australia, where ministerial offices are separate from the bureaucracy, 'The non-partisan public service has virtually no place within Ministers' offices' (O’Malley 2017: 410).

It is less clear whether the growth of 'irregular' appointees was 'a direction of travel or a blip' (interview with Whitehall think-tank research fellow, 12 December 2017). Nonetheless, 'the informal cap on [special adviser] numbers has ... been circumvented by appointing individuals as time-limited civil servants' (cited in Richardson 2018: 220). In recruiting these staff, ministers could draw on resources from outside the civil service. 'Because the relationship was [now] so bad', officials saw EMOs 'as another way of pushing them to the back of the queue' (interview with former departmental permanent secretary, 6 April 2018). While the literature focuses on special advisers (Rhodes 2011), bringing in other outsiders favoured by ministers sidelines career civil servants. There are few regulations governing these appointments. The growth of 'policy-related politicization', in which officials supportive of the administration's policies are appointed to key positions, is striking (Gouglas and Brans 2016). One permanent secretary admitted, 'Patronage got significantly worse after 2010 in appointments to public bodies and agencies' (interview with departmental permanent secretary, 19 October 2016).

For Cameron and Maude, the reforms enlarged ministers' capacity to govern. The cumulative effect was to reduce resource dependency. Of course, the situation varied between departments, underlining the contextual nature of power in Whitehall. Yet while power is contingent, the pattern was of growing civil service compliance and subordination. The growth of 'irregular' appointees undermined permanent officials. Ministers were less likely to view their relations with civil servants as important. The pluralization of policymaking represented another assault on civil service influence, a theme elaborated in the next section.

\section{Pluralizing policy and delivery}

The second element of the post-2010 reforms meant opening up Whitehall to external influence. The Cameron administrations weakened power dependency further, eroding officials' oversight of the policy process through 'open' policymaking. The 2012 plan announced a $£ 500$ million contestable policy fund (CPF), encouraging departments to pluralize policy formation. The aim was to 'commission high quality advice from outside the civil service on Ministers' priority areas; draw directly on the thinking, evidence and insight of external experts; and achieve a potentially broader and more radical range of options than Ministers would receive internally' (HM Government 2012). 
As a consequence, 'External sources are given the opportunity, through competition, to develop policy' (House of Commons 2013b). The former cabinet secretary, Lord Turnbull, applauded the initiative:

We [the civil service] no longer claim a monopoly over policy advice. We welcome the fact that we are much more open to ideas from think-tanks, consultancies, governments abroad, special advisers, and frontline practitioners. In developing policy, we not only consult more widely than we used to but involve outsiders to a far greater degree in the policy-making process [through] the extensive use of outside reviewers - Turner, Eddington, Sandler, Higgs, etc. (Turnbull 2005)

Even so, many civil servants felt diminished. Opening up policymaking was not unprecedented. Royal Commissions were replaced by 'celebrity reviews', notably the Dilnot Review, 'where a big name was asked to do a quick-fire study at the behest of Ministers'; 'arm's length' public bodies were established, such as the Low Pay Commission (Rutter 2013). Yet the CPF marked an important shift. Officials were now 'enablers and expert process designers rather than trying to monopolise policy-making input behind closed doors' (Rutter 2013). Ministers were free to determine policy using think-tanks and management consultancies; officials were losing influence to 'policy entrepreneurs' (Richardson 2018: 12).

Maude believed civil servants should focus on implementation (Aucoin 2012). As a consequence, officials were 'significantly marginalised' from the policymaking process (Waller 2012). The relationship between permanent secretaries and ministers was 'the critical fracture point in the Civil Service structure' (Richardson 2018: 12). Although 'one shouldn't go to the opposite extreme and say civil servants don't matter ... The monopoly [over policymaking] has ended' (interview with former head of a Whitehall think-tank, 30 September 2016). While 'the civil service does retain a role', it was confined 'to turning ideas into practical policy' (interview with senior official in the Department for Education and the Ministry of Justice, 7 October 2016). Officials were required to pursue initiatives according to targets set by politicians (Richards and Smith 2016; Richardson 2018). The IfG warned that, 'contrary to the popular narrative', the civil service said 'yes, Minister'. As a result, 'the Civil Service has willingly taken on extreme levels of risk in support of ministerial agendas' (cited in Richardson 2018: 17).

The crucial actors in the new policy landscape were think-tanks. Think-tanks are important players: 'proactive policy pioneers' bridging 'ideas, analysis and action' (Fraussen and Halpin 2016: 117). Think-tanks 'construct the frameworks within which policy problems are understood' (Bentham 2006: 170; Stone 2006). Of course, 'think-tanks tend to overestimate their importance; they rarely produce new ideas' (interview with Whitehall think-tank research fellow, 12 December 2017). Even so, think-tanks undermine 'enclosed policy communities ... dominated by an alliance of professionals and mandarins' (Moran 2003: 157).

Management consultants increased contestability. The use of consultants grew from the 1990s. Spending rose significantly. ${ }^{3}$ Management consultants were seconded into central units. Consultants were employed to professionalize outsourcing and commissioning. Consultants addressed skills shortages, undertaking 
commercially sensitive projects where civil servants lacked expertise (Craft and Howlett 2012). Helen Gunter et al. (2015) identified the growth of the 'consultocracy'. For 30 years 'public policy makers have increased their use of management consulting knowledge in reforming their bureaucracies' (Saint-Martin 1998, p. 41). Management consultants act as 'hired guns' in bureaucratic battles (Craft and Howlett 2012).

Yet consultants are less inclined to provide unwelcome advice to ministers. Glenn Morgan et al. (2017) chart the influence of consultants globally. They note that consultants promote the marketization of the public sector. Critics focus on the 'entrepreneurial' interests of consultancies and their propensity to undermine legitimacy (Stone 2006). Models used by management consultants invariably encourage the fragmentation of the state. For example, reforms that separate purchasers from providers in the National Health Service (NHS) originated in plans devised by consultants (Saint-Martin 1998). The legacy of the purchaser-provider split is a less integrated NHS (interview with former minister, 11 February 2012). Moreover, management consultants provide resources external to the core executive: they further undermine the exchange relationship between officials and ministers.

\section{New advisory bodies}

A further shift in power dependency relates to the proliferation of advisory bodies. In 2010, the Office for Budgetary Responsibility (OBR) was established to assess fiscal policy independently. The OBR departed from established decision-making processes where civil servants advised ministers (Rutter 2013). Governments 'externalized' responsibility, installing operationally independent authorities and regulators (Craft and Halligan 2015: 3; Halligan 1995). Advisory systems and hybrid public bodies, including 'What Works' centres, emerged that challenged departmental policymaking. Departments were no longer necessarily pre-eminent actors in the policy process.

Despite the PM's rhetoric about a 'bonfire of the quangos', agencies proliferated in the Cameron years. The growth of public bodies made governance increasingly convoluted. The externalization of policymaking led to a fragmented decisionmaking arena (Van den Berg 2016). Meanwhile, there was a plethora of inspectorates and public bodies monitoring performance. This fragmented state was operating 'in the shadow of hierarchy' (Fawcett 2014).

Reform of departments

Consequently, the ministerial/official 'governing marriage' at the heart of the Whitehall model degenerated. Policy advice meant 'sharing truth with multiple actors' (Grube and Howard 2016: 37). The fracturing of power dependency led to major changes in departments. For instance, the situation inside the Department for Education became toxic. A report by the NAO found that 'There is a lot of fear. Staff feel if they put their heads above the parapet they will be seen as an awkward character who could be got rid of (Garner 2011). According to an official,

Michael Gove was at war with his department ... over fundamental issues of policy and what the department is for. The Department for Education is now a different organization to what it was in 2010. It is much more operational, much more involved in schools. The department's policymaking capacity, its 
ability to give ministers the support they needed, had been utterly gutted in this period. (Interview with former Treasury and Cabinet Office official, 11 January 2018)

The exchange relationship between politicians and officials was eroding. Ministers no longer depended on the permanent bureaucracy. As a consequence, 'In Anglo-American democracies in particular, career public servants [have been] subject to an assault by politicians that was unprecedented in this century' (Aucoin 2012: 113; cited in Peters and Savoie 2012: 31). The centralization of power in Whitehall exacerbated that trend.

\section{Strengthening the centre}

The final set of reforms necessitated the centralization of government. Centralization further diminished resource dependency. Ministers increasingly looked to Number 10 rather than departmental officials in formulating policies. PMs are rarely completely ascendant. They rely on cabinet colleagues and departments. Yet Cameron built up prime ministerial influence, increasing his power relative to departments, undermining institutional power dependency (Heffernan 2003). When the Conservatives were elected, the incoming PM had noted, 'Politicians, and the senior civil servants and advisers who work for them, instinctively hoard power because they think that's the way to get things done. Well we're going to have to kill that instinct' (cited in Freeguard et al. 2015). An observer commented, 'Cameron came into office and it was very much a reaction against the Blair years' (interview with Whitehall think-tank research fellow, 12 December 2017). The Delivery Unit was dismantled. The Policy Unit shrank. More civil servants were appointed in Downing Street. The coalition agreement committed Cameron to cut back the size of Number 10. By March 2011, there were 73 officials in 10 Downing Street, compared to 145 under Blair (Hansard 2012). Cameron created 'a civil service-led policy unit' (interview with former departmental permanent secretary, 6 April 2018).

Yet within two years, the Policy Unit re-emerged with a political head. By 2012, Cameron and his chancellor, George Osborne, were perplexed by the centre's inadequate 'early warning system'. It failed to alert them to radical proposals that transferred NHS commissioning to general practitioners (GPs). The NHS chief executive, David Nicholson, described it as 'a reorganisation so big you can see it from outer space' (cited in Freeguard et al. 2015). The PM was initially unaware of the reforms (D'Ancona 2014). The plans were watered down to gain the agreement of Cameron's coalition partners.

Without a strong politically attuned centre, it was accepted that chaos would ensue in the policy process. Cameron thus built capacity to intervene, enlarging Number 10. The Policy Unit gave the prime ministerial centre a 'brain' alongside 'delivery reach into departments' (interview with Whitehall think-tank research fellow, 12 December 2017). Policies became increasingly centralized and top-down (Dorey 2014). Targets were replaced by departmental business plans with 'strategic objectives' - targets by another name. The Efficiency and Reform Group (ERG) was established, centralizing procurement. The ERG delivered $£ 14.3$ billion of savings 
(Freeguard et al. 2015). Observers believed PMs had little choice but to aggregate power. Number 10 enabled the PM's advisers to exert influence throughout Whitehall. The 'centralisation of executive power' continued under Cameron (Donnelly 2019: 90), depleting resource dependency.

\section{Recruitment of political advisory staff}

Centralization in Whitehall was augmented by the growth of political advisory staff. The number of advisers peaked at 103 in 2014 (with 40 employed in Number 10). Since the 1990s, 'there has been a growing tendency to employ politically appointed special advisers to service ministers' (Qvortrup 2005). According to the Code of Conduct for Special Advisers, they provide 'a political dimension to the advice and assistance available to Ministers while reinforcing the political impartiality of the permanent Civil Service by distinguishing the source of political advice and support' (HM Government 2018). Officials claim to welcome advisers: 'Permanent Secretaries/Director-Generals report they highly value Special Political Advisers (SPADs) as a working relationship has evolved whereby SPADs facilitate and position key messages from Civil Servants to be positively received by Ministers' (cited in Freeguard et al. 2015). That said, while appointees do not necessarily politicize Whitehall, advisers reshape the culture. Appointees can marginalize civil servants (Grube 2015): political staff were a 'critical mass', while bureaucrats were treated as 'an obstacle to be overcome' (Bakvis and Jarvis 2012: 16; Grube 2015). Secretaries of state now had support from junior ministers, non-executive departmental directors, parliamentary private secretaries, political advisers and experts (Rutter 2013). That vast 'entourage' could block civil service advice from reaching ministers (Van den Berg 2016: 65).

While the number of advisers grew, their remit widened from political oversight to intervening in delivery. Dominic Cummings, then special adviser to Michael Gove, directed the academy and free schools programme (Diamond 2018). Iain Duncan Smith's policy adviser invented the Universal Credit reforms virtually single-handed: Whitehall was characterized 'by more activist ministers and advisers' (interview with Whitehall think-tank director, 30 September 2016). An expert observed, 'Special advisers made a huge difference by challenging the monopoly over policy analysis, acting as policy entrepreneurs in government' (interview with Whitehall think-tank director, 30 September 2016). Ministers were now less dependent on officials. The authority of the civil service was waning, another driver of declining resource dependency. Table 1 summarizes the post-2010 reforms.

\section{Discussion and conclusions}

In light of this analysis, does the core executive still offer a plausible account of bureaucratic politics and the ministerial-civil service relationship following institutional changes during the Cameron premiership? It is averred that key assumptions of resource dependency and the contingency of power are questionable in the light of empirical evidence. This argument about the erosion of dependency is largely made from civil servants' perspective, although ministerial views are addressed. Drawing on interviews, it is apparent that: 
Table 1. Summary of Post-2010 Whitehall Reform Programme

\begin{tabular}{|c|c|}
\hline Date & Reform \\
\hline June 2010 & Independent Office for Budgetary Responsibility (OBR) established \\
\hline September 2010 & Efficiency and Reform Group (ERG) created \\
\hline December 2010 & Strengthening of Whitehall departmental boards with non-executive directors \\
\hline February 2012 & Publication of the Civil Service Reform Plan \\
\hline July 2012 & Number 10 Implementation Unit established \\
\hline February 2013 & Creation of Contestable Policy Fund (CPF) \\
\hline July 2013 & Launch of extended ministerial offices (EMOs) \\
\hline February 2014 & $\begin{array}{l}\text { Guidance on ministerial involvement in permanent secretary appointments } \\
\text { issued }\end{array}$ \\
\hline October 2014 & Civil service CEO appointed \\
\hline June 2016 & Civil service headcount reaches its lowest level since World War II \\
\hline
\end{tabular}

- Ministers relied less on official advice to make policy after 2010. They invariably entered government with an ideational agenda that was predetermined. They used experts to supply policy-relevant knowledge. Alternative delivery structures emerged that prioritized private providers. The exchange relationship enshrined in the form of a 'public service bargain' was declining.

- The erosion of resource dependency was encouraged by the pluralization of policymaking. Think-tanks were particularly influential. Officials and ministers were no longer an 'indivisible elite' in control of policy formulation (Marsh et al. 2001).

- Whitehall's centralization continued. The PM amassed resources in Number 10. The number of appointees grew. Ministers looked to Downing Street for the lead on policy. Departments as policy actors were diminished. Institutional capacity declined due to fiscal austerity.

What are the actual implications of these changes? Officials confronted a 'perfect storm' of austerity, declining capability, politicization and UK fragmentation (Pyper 2020). The dominant theme was 'organized chaos' and turbulence. For instance, an official believed the Ministry of Justice (MoJ) became 'utterly dysfunctional but at the same time a huge public policy disaster was unfolding ... The prison system pretty much collapsed ... the machine was gutted' (interview with former Treasury and Cabinet Office official, 11 January 2018). Whitehall was arguably less effective: 'the senior ranks of the civil service were massively demoralized'. Dennis Grube's (2015) concept of 'megaphone bureaucracy' highlighted that officials were more likely to speak out. Civil servants no longer trusted ministers to defend them.

Whitehall was dispirited by the perceived growth of policy fiascos. Katy Wilkinson's (2011) study of the Department of the Environment, Fisheries, and Agriculture (DEFRA) found policymaking was 'anarchic'. Anthony Crewe 
and Ivor King (2013: 5) attest that blunders were 'rooted in poorly designed policymaking and delivery structures'. There were errors due to 'less time and space for reflection on, and consideration of, evidence' (Crewe and King 2013: 5). The paradox is that a greater range of policy advice was sought, yet the 'deliberation deficit' grew markedly. External actors were prone to tell ministers only what they wanted to hear. Appointees controlled the flow of information. Meanwhile, the policymaking process grew more byzantine. Notable failures included Universal Credit and the Troubled Families Programme.

When Iain Duncan Smith was appointed secretary of state at the DWP in 2010, plans for Universal Credit were circulating through the Centre for Social Justice think-tank. Officials played little role in shaping the policy (Rutter 2013), while Universal Credit was never stress-tested. Implementation problems identified by the front line were ignored. Civil servants were reluctant to tell ministers the proposals were flawed (Aucoin 2012). The Troubled Families Programme similarly created problems. Paul Cairney believes it was an example of 'policy-based evidence-making'. The initiative made assumptions 'about who the "troubled families" are, what causes their behaviour, and how to stop it'. Civil servants were not allowed to test this premise properly (Cairney 2019: 5). Ministers had entered government with 'an ideational policy portfolio ... [and] their own strong priorities on what policy change is needed' (Richardson 2018: 12).

In this 'microwave not slow cooker' policymaking environment, actions were agreed without enough deliberation (interview with departmental permanent secretary, 19 October 2016). The fracturing of resource dependency undermined Whitehall's policy and implementation systems. From a meta-governance perspective, the reforms that implanted a 'them and us' model in Whitehall appear to have weakened the state's capacity to govern. As the 'close, co-operative relationship' between ministers and officials eroded, reflecting underlying changes in the PSB (Tiernan 2011), policymaking became less effective. Similar patterns of breakdown in resource dependency can be observed elsewhere in anglophone countries (Craft and Halligan 2020) and in European states, notably Denmark, where there is growing evidence of politicization within the permanent bureaucracy and the emergence of personalized court politics (Rhodes and Salomonsen 2021).

Mark Garnett (2021: 228) emphasizes that 'the core executive approach overlooked the possibility that the best term to describe the British system was not "prime ministerial" or "presidential", but dysfunctional'. The core executive concept was better suited to explaining post-1997 Blair-era governance that emphasized 'joining up' and horizontal coordination. Yet empirical reality increasingly diverged from the model after 2010, as the Cameron administration sought to renegotiate the prevailing PSB. The Johnson government shows few signs of reversing course. Smith (1999: 106) attests, 'The analysis of ministerial-civil service relations has been framed in terms of who has power ... [and] such a criterion oversimplifies these relationships.' Even so, the interaction is no longer centred on resource dependency. The core executive was an ideal-type that told ministers and officials how to behave to deliver their policies (Garnett 2021). If both sides worked collectively, the result was ostensibly improved policymaking. During Cameron's premiership, however, Whitehall reforms depleted ministerial dependency, not least by centralizing policy deliberation, ensuring ministers looked to Number 10 rather than departments (Diamond 2018). As such, changes in power dependency at 
the interpersonal and institutional level were closely intertwined. Ministers relied less on both officials and their own departments. The evidence indicates a shift occurred from resource dependency to a 'them and us' model centred on the principal-agent dichotomy. As such, in understanding the bureaucratic politics of central government, scholars must revisit the main assumptions of the core executive model.

\section{Notes}

1 It was Peter Madgwick who first elucidated the concept of 'the central executive territory'.

2 In the case of the Prisons' Agency and the home secretary, Michael Howard in the early 1990s, the minister's attempt to evade blame for breaches of prison security did significant damage to his political career. 3 In 2016, the NAO reported that spending across 17 central government departments had doubled since 2011-12 to $£ 1.3$ billion per annum. Most contracts went to six major firms, according to the NAO: Pricewaterhouse Coopers, Deloitte, KPMG, McKinsey, Ernst \& Young and PA Consulting. The peak of spending on consultants was $£ 1.8$ billion in 2008-9. A subsequent NAO report in April 2019 found that Whitehall departments spent $£ 97$ billion on Brexit-related contracts.

\section{References}

Aucoin P (2012) New Political Governance in Westminster Systems: Impartial Public Administration and Management Performance at Risk. Governance 25(2), 177-199. https://doi.org/10.1111/j.1468-0491. 2012.01569.x.

Bakvis H and Jarvis MD (eds) (2012) From New Public Management to New Political Governance: Essays in Honour of Peter Aucoin. Montreal: McGill-Queen's University Press.

Bell S and Hindmoor A (2009) Rethinking Governance: The Centrality of the State in Modern Society. Cambridge: Cambridge University Press.

Bentham J (2006) The IPPR and Demos: Think-Tanks of the New Social Democracy. Political Quarterly 77(2), 166-176. https://doi.org/10.1111/j.1467-923x.2006.00759.x.

Boswell J et al. (2019) State of the Field: What Can Political Ethnography Tell Us about Anti-Politics and Democratic Disaffection? European Journal of Political Research 58(1), 56-71. https://doi.org/10.1111/ 1475-6765.12270.

Butler D et al. (1994) Failure in British Government: The Politics of the Poll Tax. Oxford: Oxford University Press.

Cairney P (2019) The UK Government's Imaginative Use of Evidence to Make Policy. British Politics 14(1), 1-22. https://doi.org/10.1057/s41293-017-0068-2.

Cameron S (2017) Bashing the Bureaucrats Can Only Backfire. Daily Telegraph, 18 December.

Campbell C and Wilson GK (1995) The End of Whitehall: Death of a Paradigm? Oxford: Blackwell.

Craft J and Halligan J (2015) Assessing Thirty Years of Westminster Policy Advisory System Experience. Policy Sciences 50(1), 47-62. https://doi.org/10.1007/s11077-016-9256-y.

Craft J and Halligan J (2020) Advising Governments in the Westminster Tradition: Policy Advisory Systems in Australia, Britain, Canada and New Zealand. Cambridge: Cambridge University Press.

Craft J and Howlett M (2012) Policy Formulation, Governance Shifts and Policy Influence: Location and Content in Policy Advisory Systems. Journal of Public Policy 32(2), 79-98. https://doi.org/10.1017/ S0143814X12000049.

Crewe I and King A (2013) The Blunders of Our Governments. London: One World Publications.

D'Ancona M (2014) In It Together: The Inside Story of a Coalition Government. London: Viking.

De Volo L and Schatz E (2004) From the Inside Out: Ethnographic Methods in Political Research. Political Science and Politics 37(2), 267-71. https://doi.org/10.1017/S1049096504004214.

Diamond P (2018) The End of Whitehall? Government by Permanent Campaign. Basingstoke: Palgrave Macmillan.

Dommett K and Flinders M (2016) The Centre Strikes Back: Meta-Governance, Delegation and the Core Executive in the UK 2010-14. Public Administration 93(1), 1-16. https://doi.org/10.1111/padm.12121. 
Donnelly M (2019) Improving Governance. National Institute Economic Review 250(1), R89-R93.

Dorey P (2014) Policy-Making in Britain. London: Sage.

Dorey P (2020) The Core Executive. In Garnett M (ed.), The Routledge Handbook of British Politics and Society. London: Routledge, pp. 21-38.

Dunleavy P and Rhodes RAW (1990) Core Executive Studies in Britain. Public Administration 68, 3-28. https://doi.org/10.1111/j.1467-9299.1990.tb00744.x.

Elgie R (2011) Core Executive Studies Two Decades On. Public Administration 89(1), 64-77. https://doi. org/10.1111/j.1467-9299.2011.01899.x.

Fawcett P (2014) Critical Encounters with Decentred Theory: Tradition, Metagovernance, and Parrhesia as Story-Telling. In Turnbull N (ed.), Interpreting Governance, High Politics and Public Policy: Essays Commemorating Interpreting British Governance. London: Routledge, pp. 36-44.

Foster C (2015) Cabinet Office Minister Francis Maude: 'You Don't Need to Be an MP to Do My Job', Civil Service World, 30 April.

Fraussen B and Halpin D (2016) Think Tanks and Strategic Policy-Making: The Contribution of Think Tanks to Policy Advisory Systems. Policy Sciences 50(1), 105-124. https://doi.org/10.1007/s11077-0169246-0.

Freeguard G et al. (2015) Whitehall Monitor 2015. London: Institute for Government.

Garner R (2011) Crisis of Confidence among Civil Servants in Gove's Department. Independent, 23 September.

Garnett M (2021) The British Prime Minister in an Age of Upheaval. London: Routledge.

Gay O et al. (2015) The Coalition and the Decline of Majoritarianism in the UK. Political Quarterly 86(1), 118-124. https://doi.org/10.1111/1467-923X.12148.

Goes E (2016) The Labour Party under Ed Miliband. Manchester: Manchester University Press.

Gouglas A and Brans M (2016) UK Extended Ministerial Offices: On the Road to Cabinetisation? Blog, Constitution Unit, 9 February. https://constitution-unit.com/2016/02/09/uk-extended-ministerialoffices-on-the-road-to-cabinetisation/.

Grube D (2015) Responsibility to Be Enthusiastic? Public Servants and the Public Face of 'Promiscuous Partisanship'. Governance 28(3), 305-320. https://doi.org/10.1111/gove.12088.

Grube D and Howard C (2016) Is the Westminster System Broken beyond Repair? Governance 29(4), 467-481. https://doi.org/10.1111/gove.12230.

Guerin B (2020) Civil Service Staff Numbers. London: Institute for Government.

Gunter HM, Hall D and Mills C (2015) Consultants, Consultancy and Consultocracy in Education Policymaking in England. Journal of Education Policy 30(4), 518-539. https://oi.org/10.1080/ 02680939.2014.963163.

Haddon C (2016) Developments in the Civil Service. In Heffernan R et al. (eds), Developments in British Politics 10. Basingstoke: Palgrave Macmillan, pp. 161-181.

Halligan J (1995) Policy Advice and the Public Service. In Peters BG and Savoie DJ (eds), Governance in a Changing Environment. Montreal: McGill-Queen's University Press, pp. 138-172.

Hansard (2012) Written Question: Government Departments: Staff, HL Deb House of Lords, 14 March, col. WA72. https://publications.parliament.uk/pa/ld201212/ldhansrd/text/120314w0001.htm\#12031477001015.

Hansard (2014) HC Deb, 14 January 2014, Vol. 565, col. 341. https://publications.parliament.uk/pa/ ld201314/ldhansrd/text/140116-0001.htm.

Hazell R (2012) How the Coalition Works at the Centre. In Hazell R and Yong B (eds), The Politics of Coalition: How the Conservative-Liberal Democrat Government Works. Oxford: Hart Publishing, pp. 49-71.

Heffernan R (2003) Prime Ministerial Predominance: Core Executive Politics in the UK. British Journal of Politics and International Relations 5(3), 347-372. https://doi.org/10.1111/1467-856X.00110.

HM Government (2012) The Civil Service Reform Plan. London: HM Government.

HM Government (2018) The Code of Conduct for Special Advisers. London: HM Government.

Hood C and Lodge M (2006) The Politics of Public Service Bargains: Reward, Competency, Loyalty and Blame. Oxford: Oxford University Press.

House of Commons (2013a) Public Administration and Constitutional Affairs Select Committee Second Report: The Future of the Civil Service. London: House of Commons.

House of Commons (2013b) Public Administration and Constitutional Affairs Select Committee Second Report: Public Engagement in Policy-Making. London: House of Commons. 
Le Grand J (2006) Of Knights and Knaves: Motivation, Agency and Public Policy. Oxford: Oxford University Press.

Lowe R (2011) The Official History of the British Civil Service: Reforming the Civil Service Volume I: The Fulton Years 1966-81. London: Routledge.

Lukes S (1974) Power: A Radical View. Basingstoke: Macmillan.

Marinetto M (2003) Governing Beyond the Centre: A Critique of the Anglo-Governance School. Political Studies 51(3), 592-608. https://doi.org/10.1111/1467-9248.00443.

Marsh D, Richards D and Smith M (2001) Changing Patterns of Government: Reinventing Whitehall? Basingstoke: Palgrave Macmillan.

McClory J (2010) Will 'New Style' Departmental Boards Kill or Cure? London: Institute for Government.

Moran M (2003) The British Regulatory State. Oxford: Oxford University Press.

Morgan G, Sturdy A and Frenkel M (2017) The Role of Large Management Consultancy Firms in Global Public Policy. In Stone D and Maloney K (eds), Oxford Handbook on Global Public Policy and Transnational Administration. Oxford: Oxford University Press, pp. 583-98.

Niskanen WA (1971) Bureaucracy and Representative Government. Chicago: Aldine-Atherton.

O'Malley M (2017) Temporary Partisans, Tagged Officers or Impartial Professionals? Moving between Ministerial Offices and Departments. Public Administration 95(1), 407-420. https://oi.org/10.1111/ padm. 12290.

Pearce N (2016) When the Government Has an Agreed Position - As on the EU Referendum - Civil Servants Must Support It. Civil Service World, 1 March.

Pedersen A, Sehested K and Sorenson E (2011) Emerging Theoretical Understanding of Pluricentric Coordination in Public Governance. American Review of Public Administration 41(1), 372-395. https://doi.org/10.1177/0275074010378159.

Peters BG and Savoie D (2012) In Search of Good Governance. In Bakvis H and Jarvis MD (eds), From New Public Management to New Political Governance: Essays in Honour of Peter Aucoin. Montreal: McGill-Queen's Press, pp. 204-241.

Pyper R (2020) Debate: The British Civil Service: Contextualising Development Challenges. Public Money and Management, published early online, June. https://doi.org/10.1080/09540962.2020.1778256.

Qvortrup M (2005) Memorandum to the Select Committee on Public Administration - Written Evidence. London: House of Commons.

Rhodes RAW (2011) Everyday Life in British Government. Oxford: Oxford University Press.

Rhodes RAW (2017) Network Governance and the Differentiated Polity. Oxford: Oxford University Press.

Rhodes RAW and Salomonsen H (2021) Duopoly, Court Politics and the Danish Core Executive. Public Administration 99(1), 72-86. https://doi.org/10.1111/padm.12685.

Richards D and Smith M (2016) The Westminster Model and the 'Indivisibility of the Political and Economic Elite': A Convenient Myth Whose Time Is Up? Governance 29(4), 499-516. https://doi.org/ 10.1111/gove.12225.

Richardson J (2018) The Changing British Policy Style: From Governance to Government? British Politics 13(1), 215-233. https://doi.org/10.1057/s41293-017-0051-y.

Rutter J (2013) Opening-Up Policy-Making. London: Institute for Government.

Saint-Martin D (1998) Les Consultants et la Réforme Managérialiste de l'État en France et en Grande-Bretagne: Vers l'Émergence d'une 'Consultocratie'? Montreal: McGill University Press.

Sausman C and Locke R (2004) The British Civil Service: Examining the Question of Politicization. In Peters GB and Pierre J (eds), Politicisation of the Civil Service in Comparative Perspective. London: Routledge, pp. 101-124.

Schaffer B (1973) The Administrative Factor: Papers in Organisation, Politics and Development. London: Routledge \& Kegan Paul.

Smith M (1999) The Core Executive. Basingstoke: Palgrave Macmillan.

Sorenson E and Torfing J (2017) Metagoverning Collaborative Innovation in Governance Networks. American Journal of Public Administration 47(7), 829-839. https://doi.org/10.1177\% 2F0275074016643181.

Stone D (2006) Public Policy Analysis and Think Tanks. In Fischer F, Miller GJ and Sidney MS (eds), Handbook of Public Policy Analysis: Theory, Methods and Politics. New York: Marcel Dekker Inc., pp. 149-157. 
Tiernan A (2011) Advising Australian Federal Governments: Assessing the Evolving Capacity and Role of the Australian Public Service. Australian Journal of Public Administration 70(4), 335-346. https://doi. org/10.1111/j.1467-8500.2011.00742.x.

Turnbull A (2005) Valedictory Lecture. Guardian, 27 July.

Van den Berg C (2016) Dynamics in the Dutch Policy Advisory System: Externalisation, Politicisation and the Legacy of Pillarisation. Policy Sciences 50(1), 63-84. https://doi.org/10.1007/s11077-016-9257-x.

Van Dorpe K and Horton S (2011) The Public Service Bargain in the United Kingdom: The Whitehall Model in Decline? Public Policy and Administration 26(2), 233-252. https://doi.org/10.1177/ 0952076710391518.

Waller P (2012) Departments: Ministers and the Civil Service. In Hazell R and Yong B (eds), The Politics of Coalition: How the Conservative-Liberal Democrat Government Works. Oxford: Hart Publishing, pp. 71-91.

Wildavsky A (1979) Speaking Truth to Power: The Art and Craft of Policy Analysis. New York: Little, Brown.

Wilkinson K (2011) Organised Chaos: An Interpretative Approach to Evidence-Based Policy-Making in DEFRA. Political Studies 9(4), 915-944. https://doi.org/10.1111/j.1467-9248.2010.00866.x.

Wilson GK and Barker A (2003) Bureaucrats and Politicians in Britain. Governance 16(3), 349-372. https://doi.org/10.1111/1468-0491.00220.

Cite this article: Diamond P (2021). Core Executive Politics in the Cameron Era, 2010-16: The Dynamics of Whitehall Reform. Government and Opposition: An International Journal of Comparative Politics 1-19. https://doi.org/10.1017/gov.2021.47 